\title{
Article
}

\section{Hate Speech, Emotions, and Gender Identities: A Study of Social Narratives on Twitter with Trainee Teachers}

\author{
Delfín Ortega-Sánchez ${ }^{1,2, * \mathbb{D}}$, Joan Pagès Blanch ${ }^{3,+}$, Jaime Ibáñez Quintana ${ }^{1}$, Esther Sanz de la Cal ${ }^{1}$ \\ and Raquel de la Fuente-Anuncibay 4 (i)
}

check for

updates

Citation: Ortega-Sánchez, D.; Blanch, J.P.; Quintana, J.I.; Cal, E.S.d.l.; de la Fuente-Anuncibay, R. Hate Speech, Emotions, and Gender Identities: A Study of Social Narratives on Twitter with Trainee Teachers. Int. J Environ. Res. Public Health 2021, 18, 4055. https://doi.org/10.3390/ ijerph18084055

Academic Editors: Giulia Ballarotto, Silvia Cimino and Luca Cerniglia

Received: 15 February 2021

Accepted: 9 April 2021

Published: 12 April 2021

Publisher's Note: MDPI stays neutral with regard to jurisdictional claims in published maps and institutional affiliations.

Copyright: (c) 2021 by the authors. Licensee MDPI, Basel, Switzerland. This article is an open access article distributed under the terms and conditions of the Creative Commons Attribution (CC BY) license (https:/ / creativecommons.org/licenses/by/ $4.0 /)$.
1 Department of Specific Didactics, Faculty of Education, University of Burgos, 09001 Burgos, Spain; jibanez@ubu.es (J.I.Q.); esanz@ubu.es (E.S.d.l.C.)

2 Integrated Science Association (ISA), Universal Scientific Education and Research Network (USERN), Tehran 1419733151, Iran

3 Department of Language, Literature and Social Science Education, Autonomous University of Barcelona, 08193 Bellaterra, Spain; joan.pages@uab.cat

4 Department of Education Sciences, Faculty of Education, University of Burgos, 09001 Burgos, Spain; raquelfa@ubu.es

* Correspondence: dosanchez@ubu.es; Tel.: +34-947-111-832

+ In memoriam.

\begin{abstract}
The objective of this study is, on the one hand, to analyse emotional responses to the construction of hate speech relating to gender identity on Twitter. On the other hand, the objective is to evaluate the capabilities of trainee primary education teachers at constructing alternative counter-narratives to this socially alive issue, surrounding the approval of the Ley de Identidad de Género [Gender Identity Law] in Chile, in 2018. With this two-fold objective in mind, quantitative, descriptive, and inferential analysis and qualitative analysis techniques are all applied. The results inform us of the influence of socially constructed emotions and feelings that are expressed in social narratives. However, the narratives of the participants neither appeared to reach satisfactory levels of reflection on the social issues that stirred their own emotional responses, nor on the conflict between reason and the value judgements that they expressed in the digital debate (counter-narratives). These results point to the need to consider both emotions and feelings, as categories of social analysis, and to reflect on their forms of expression within the framework of education for inclusive democratic citizenship.
\end{abstract}

Keywords: hate speech; gender identities; social narratives; social education; trainee teachers; twitter

\section{Introduction}

One of the most controversial aspects of present-day social media is the digital forum where unreasoned affirmations, scornful of otherness, and social exclusion predominate. Among the most well-known spaces for the construction of these narratives of hate, or hate speech, Twitter is a network of networks of special influence in both formal and non-formal fields of education [1-4], and in the construction of perceptions of social reality.

In this investigation, the relevance of this network will be studied, in relation to its coverage of issues relating to political interest and civil activism [5-9], and environmental challenges and social problems, such as gender inequalities [10-12]. Despite its democratic potential, its functional operation as a social space for the emergence of hate speech against social, cultural, sexual, and religious minorities will also be examined, based on the construction of antagonistic narratives that deny dialogical participation and promote symbolic violence [13].

The presence of groups in a contextualized situation of vulnerability has to be recognized, and negative and stereotyped intentions, explicitly directed at humiliation and social segregation, have to be identified, in order to consider the existence of hate speech 
or narratives of hate $[14,15]$. Their constructive basis is the 'image of the enemy' and, in consequence, they are contrary to the idea of diversity (Figure 1).

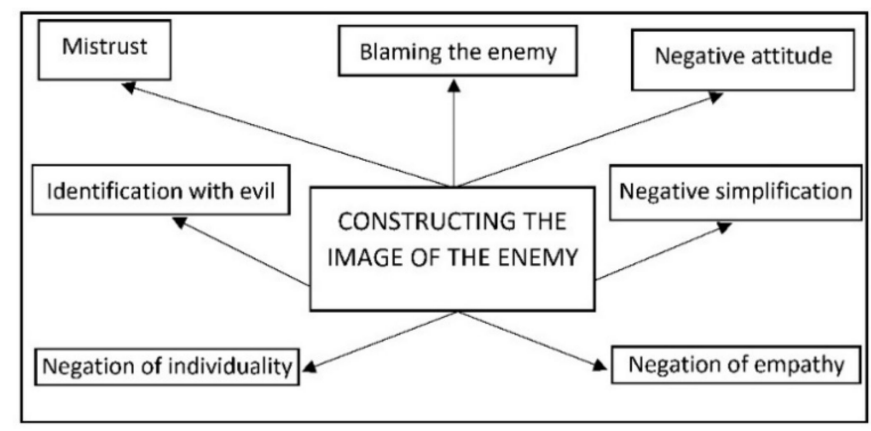

Figure 1. Constructing the image of the enemy $[16,17]$.

The European Commission against Racism and Intolerance of the European Council defined hate speech or incitation to hatred as: "The advocacy, promotion or incitement of the denigration, hatred or vilification of a person or group of persons, as well any harassment, insult, negative stereotyping, stigmatization or threat of such person or persons and any justification of all these forms of expression - that is based on a non-exhaustive list of personal characteristics or status that includes "race", colour, language, religion or belief, nationality or national or ethnic origin, as well as descent, age, disability, sex, gender, gender identity and sexual orientation" ([18], pp. 2-3).

In the narratives on hatred, the emotions predominate over and above rationality. In fact, most of their affirmations are not consistent when justified with facts, data, and arguments [19]. Cognitivists, sociologists, and anthropologists have maintained that both emotions and feelings have a direct influence on the following: perceptions of social reality and its future path, communications, personal decision-making, creativity and value systems [20-23]. In fact, the first large-scale systematic studies on the measurement of hate speech on social media (Whisper and Twitter) and their analysis, covered in the study of Mondal et al. [24], provided evidence of these patterns and their presence on the construction of the narratives.

Working with narratives on hate in the classroom constitutes one of the educational demands of our day and age. The Council of Europe [25] has, on this point, promoted specific actions to combat these sorts of narratives on social media, through the promotion of human rights, democratic participation, and preliminary courses on the critical analysis of the communications media. Teacher-training programmes have to incorporate these digital social narratives or stories, in particular, those who generate hate, to work with them and to offer the necessary tools to counter them with democratic values and the principles of social justice.

The teaching of social sciences must intervene in the training of the critical thought processes of students for the dialectical interpretation of social reality, intervention in social problems [26], and the promotion of alternative narratives to hate speech. The construction of these counter-narratives, alternative stories or narrative forms for the "development of critical thought oriented towards social action" ([16], p. 428), ought to "help to interpret the role of the emotions in hate narratives and to offer information to position reason in opposition to irrationality" ([16], p. 427), revealing their contradictions and their stereotypes.

In this context, the objective of the present research is to analyse the mediating roles of the emotions, bias, and partiality in digital social narratives [27] in relation to socially alive issues within public debates, in particular, on the Twitter social network. It likewise seeks to evaluate the way in which social sciences trainee-teachers of place reason in opposition to value judgements expressed on Twitter for managing and changing mediating emotions, especially when they are "negative, perverse, or inconvenient" ([21], p. 32). From this perspective, the capabilities of trainee-teachers to construct alternative social counternarratives to digital hate stories concerning gender inequalities will be determined, in the context of the recent approval in Chile of the Gender Identity Law. 
This paper is structured in the following sections and subsections: Section 1. Introduction; Subsection 1.1. Influence of emotions in the construction of social narratives and its role in education for democratic and inclusive citizenship; Section 2. Materials and Methods; Subsection 2.1. Design and procedure; Subsection 2.2. Participants; Subsection 2.3. Instrument; Subsection 2.4. Data analysis; Section 3. Results; Subsection 3.1. Quantitative content analysis; Subsection 3.2. Qualitative content analysis; Subsection 3.2.1. First category: beginner; Subsection 3.2.2. Second category: intermediate; Subsection 3.2.3. Third category: expert; Section 4. Discussion; Section 5. Conclusions; Section 6. Limitations.

\subsection{Influence of Emotions in the Construction of Social Narratives and Its Role in Education for Democratic and Inclusive Citizenship}

According to Morgado: "our social behavior, that is, our entire relationship with other people, is particularly influenced by emotions and feelings" ([21], p. 32). Emotions, understood as social constructions, constitute, therefore, a valid category of social analysis and object of cultural study [28]. From this perspective, the changing social and cultural nature of the forms of expression of emotions allows that "they can be harnessed to visualize the historical and social meaning of internal or subjective life" ([28], p. 189).

Despite the proximity and semantic relationship between emotion and feeling, Damasio [29] identifies the boundary between the two terms in the space, subjective or social, in which they are experienced. Indeed, while feeling starts from the mental and private experience of emotion, emotion represents its manifestation, usually external, observable and, therefore, measurable. Consequently, emotions would be the most recognizable expressions in social interpretation and explanation.

The highlighting of emotions in the teaching of social knowledge and in teacher training renounces the reason-emotion split, characteristic of modern rationality [29], to explain social behavior by integrating the intervention of emotions. Emotions, in fact, "cohere the feeling of community of individuals and human groups, and are expressed in recognizable gestures" ([30], p. 357). This emotional and affective cohesion was demonstrated in the use by secondary education students of certain exclusionary political and historical narratives during the Chilean feminist movement in 2018 [31]. Similarly, it could be evidenced in the digital analysis of the \#MeToo movement, in which the polarized use of aggressive and destructive language versus more positive ones oriented towards education and the defense of human rights was identified [32].

The incorporation of emotional experience in the training of future teachers, and the analysis of the relationship between emotions and social change [33] become valid categories for the understanding, interpretation and explanation of a naturally plural and diverse social reality. In this sense, working digital critical literacy in the teaching of social sciences implies revealing emotions as stimuli that induce a certain affective sociability. Anger, one of the most recognizable universal primary emotions in public social behavior or hate permeate human history, and thus shape its social narratives [34], especially, social narratives of hate.

Recent research on the LGBT community has focused on the analysis of emotional wellbeing and the impact of health inequalities, particularly for transgender people. Within the scope of these inequalities, emotions are placed in a central place, whose adversities are found in all spaces of social relations, including the digital, the educational and the health care [35].

The high frequency of use among university students [36-38] and adolescents of Twitter for self-expression, communication, information exchange, and the emergent and cooperative preparation of multi-modal narratives [39,40], as well as the positive attitudes of teaching staff towards their communicative potential for professional development have been sufficiently well studied [41,42]. Nevertheless, investigations that are specifically directed toward the analysis of hate speech on the most popular digital media and its effects on people, social groupings, and collectives are scarce, and almost inexistent in the context of Latin-America.

Despite the recognition of the difficulties of detecting hate speech in social networks, there have been significant technological advances in identifying, semantically capturing, 
and automatically monitoring tweets aimed at constructing this type of speech on Twitter [43-45]. However, there has been very little research focused on social science teacher education and the analysis of its implications for democratic citizenship education.

The most recent, from the sociological perspective, may be found in the work of Lingiardi et al. [46], who applied a lexical analysis of semantic context within the framework of the project 'Map of Italian hate', with the objective of completing a 'social snapshot' of behaviours and social attitudes. Their results confirmed that women and the LGTBIQ collective were found among the most hated groups on Twitter.

On the basis of the above objectives, the following research questions are proposed:

(1) Is there a statistically dependent relation between the sex of the participant and the emotions experienced after reading the digital debate, in Spanish, on the approval of the Chilean Gender Identity Law?

(2) Will significant relations of interdependency be noted between the tweets of the digital debate, the emotions that are experienced, and their textual justifications?

(3) How will trainee-teachers describe their manifest and/or latent emotions? Will they achieve satisfactory levels of reflection and/or justification for the construction of social counter-narratives to hate?

\section{Materials and Methods}

\subsection{Design and Procedure}

The study can be described as a mixed method sequential explanatory design approach [47]. It was planned in two phases: the first directed towards the collection and analysis of quantitative data (from 3 to 5 December 2018), and the second was centred on the collection (from 12 December to 14 December 2018), analysis, description, interpretation, and evaluation of qualitative data. The second phase sought to triangulate and to improve understanding of the quantitative results [48].

The sequential explanatory design (DEXPLIS) is characterized by the integrated followup of two research stages: in the first, quantitative data are collected and analyzed and, in the second, qualitative data are collected and interpreted. From this methodological procedure, "the mixed mixture occurs when the initial quantitative results inform the collection of qualitative data" ([47], p. 566).

Specifically, our purpose was to use, as a priority, the qualitative results to assist and deepen the explanation of the initial quantitative results. In this sense, DEXPLIS was used in the study to "characterize cases" ([47], p. 566) [in our study, a classroom of the last year of the primary education degree], through the features and elements of interest of the proposed research problem.

A deductive approach to coding and categorization was used, as the intention was to test and extend an existing theory, and to investigate its transferability to a different social context [49]. According to this methodological approach, the following phases were followed, based on the process described in Figure 2: (1) Determination of codes and categories based on the research question. (2) Identification and definition of the textual fragments relevant to our categories. (3) Compilation of all coded segments into categories. (4) Definition of the levels for assessing the relevance of each category (5) Coding of the complete data set. (6) Exhaustive category-based analysis.

Prior to the textual analysis, a provisional code system/book and coding rule (memos) for the identification and segmentation of the qualitative data were developed and its categorization was defined. This deductive coding and categorization derived from the review of previous scientific theory and literature, in particular, the studies of Santisteban et al. [50], and Castellví et al. [51]. Once the coding system was defined and applied to the narratives under study, the three categories (beginner, intermediate and expert), suggested and also applied in the aforementioned studies, were applied according to the level of competence and critical digital literacy of the participating trainee teachers. 


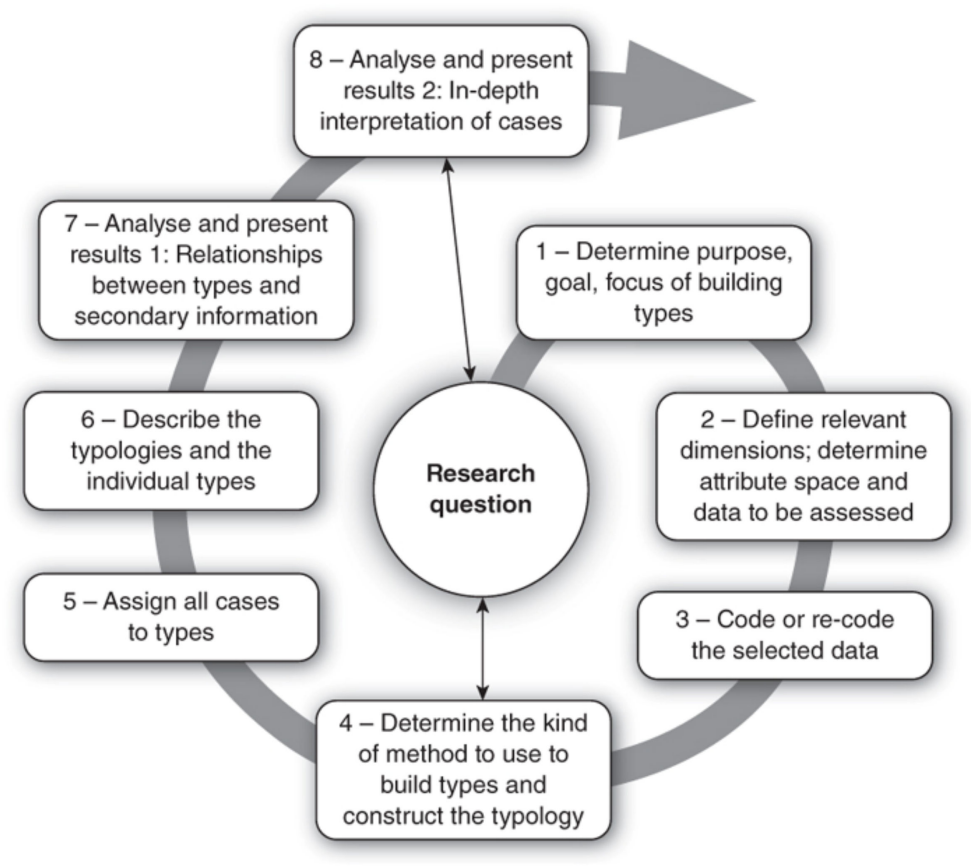

Figure 2. Qualitative research process [49].

Likewise, the case-study methodology was applied [52], with the aim of analysing the capability of a specific group of trainee teachers from a social sciences teacher-training programme on social invisibility and gender identities to construct counter-narratives. This circumstance explains the relevance of its selection and its expected potential informative and interpretative richness. The application of the instrument was completed over the last week of the year in a single 50-min session.

\subsection{Participants}

The total sample consisted of 46 trainee teachers (women: $f_{i}=34 ; 73.9 \%$; men: $\left.f_{i}=12 ; 26.1 \%\right)$, with an average age of 23.3 years $(S D=2.52)$. Non-probabilistic convenience sampling was applied to the available cases and the possibilities of the researchers to access the field of study [53]. The selection of the participants followed one single intentional criterion: to have enrolled on or to have completed a teacher training course on gender identities, social otherness, and social invisibility in the teaching of social sciences, taught by one of the principal researchers at a university in the north of Spain [54].

The sample presents a characteristic male-female distribution of the university population in the area studied, characterized by a greater presence of women. In this sense, the OECD [55] points out great differences according to the areas, greater in education (81\%) with respect to health or social services $(72 \%)$, these percentages being very similar to other European countries such as Ireland and the United Kingdom.

\subsection{Instrument}

The instrument that was applied consisted of a set of activities, designed using a digital reproduction of a real debate on the approval of the Gender Identity Law in Chile on the social network Twitter. From among the 323 tweets monitored through the API Streaming application of Twitter and posted between 28 November 2018, the date on which the law was enacted, and 2 December 2018, a total of 8 were selected on the basis of their explanatory capacity and the way they summarized the opinions and the value judgements expressed by the users of the social network. The names and the Twitter accounts of those participating in the debate were edited out of the screen shots, to protect their identities. The reading order of the pairs of tweets, presented in Table 1, is a replica of 
its sequential appearance in the social network at the time of its selection and reproduction in the classroom.

Table 1. Selection of tweets.

\begin{tabular}{c}
\hline RdOrd \\
\hline Today the gender identity law was passed, after over 5 \\
years of lobbying by @IgualesChile and @OTDChile. It \\
will mean a substantive improvement in the field of \\
Human Rights in Chile that faces great challenges in the \\
future, especially with respect to children. [Photo: \\
National ID Card My Identity / My Right] \\
Historic day. Today the Gender Identity Law has been \\
enacted. We dedicate this day to the victims of \\
transphobia, to those who were murdered for holding \\
an alternative gender identity and who died with an ID \\
card that did not represent them. So that it may never \\
happen again! \#HappyWednesday \\
[Photo: Historic Day! Today the Gender Identity Law \\
was enacted. We dedicate this historic day to the 17 fatal \\
victims of transphobia.
\end{tabular}

After years of work and struggle by the trans and LGTB

\section{organizations of Chile, Sebastián Piñera approved the new gender identity law, which depathologizes trans identities.}

Gender identity law, you won't touch our children with your twisted and fallacious concepts. [Photo: Speech bubbles Adult: "You mustn't let anybody influence your decision". Boy: "But I want to be a boy". Adult: "Shut up you oppressive macho pig! Don't ..." ]

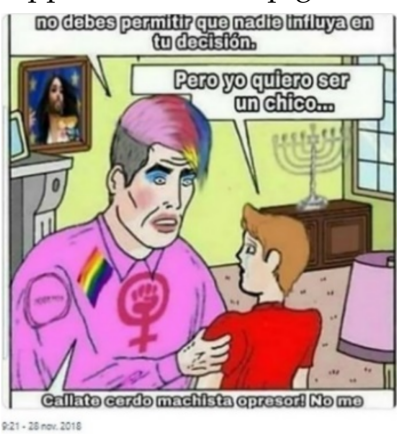

Thanks to those who supported and backed the Gender Identity Law! With the work that we have done together, Chile is a fairer and more egalitarian country. [Photo: Thanks to those who presented the motion on the Gender Identity Law;

Also to those who supported it on its way.]

Jack can now be a lamp thanks to the Gender Identity Law. [Photo: BIOLOGICALLY I WAS BORN A DOG. But thanks to gender ideology, I do in fact exist! I CAN NOW BE A LAMP if you don't agree you're cursed with dog-phobia, living in the

past ... yours faithfully Progressive Logic].

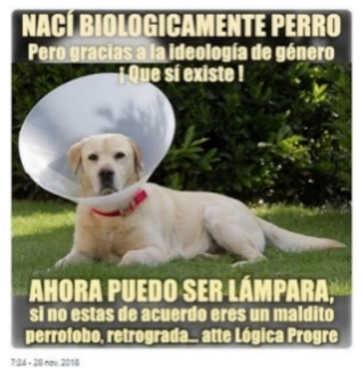

A good day for Chile! The Gender Identity Law was enacted, despite the hysteric opposition (and with no justification) of the religious ultra-right.

Common sense and the common good have prevailed, and the guarantee of civil rights and the protection of the most vulnerable.

Today is a great day, with the gender identity law an important problem has been solved that affects $0.01 \%$ of Chileans. Hopefully as from tomorrow the government will start to concern itself as much with the remaining $99.9 \%$

This selection responded to its capacity to gather a greater number of responses and, therefore, to generate debate among the participants in the discussion. In this sense, the number of interventions derived from its publication was considered for their selection. Based on this numerical orientation, in order to analyse the relevance of this selection (outstanding explanatory capacity in the set of tweets collected; ability to generate emotions in readers; and use of clear language in accordance with the emotional message conveyed), we calculated Kendall's concordance coefficient, based on the ratings expressed by two 
independent expert-judges in an interval of 1 to 5 points. The results show the existence of a high concordance index and significant homogeneity between the assigned ranges $(W=0.812, p=0.000)$, confirming the validity of the proposed selection.

The first of three activities asked the trainee teachers to select, from among a group of seven primary universal emotions-disgust/repugnance, anger, fear, surprise, happiness, sadness, and apathy- [29], a minimum of one emotion experienced after the complete reading of the digital debate. The second activity, complementary to the first, presented the eight tweets shown above (Table 1), so that the trainee-teachers could relate each one of them with one or various primary emotions. Lastly, the third activity asked the trainee teachers to draft an argumentative and/or justificatory text, of at least 5 lines, on the emotions that they had experienced (activity 1) and those they had related to each tweet (activity 2), which would contain specific references to some of the eight tweets reproduced for the activities.

The objectives of the instrument were related with student participation in the public debates on relevant social problems within the digital media, and with the capabilities of the trainee teachers to interpret them in a critical manner. Its design was therefore based on the need for close examination of the experiences [56] and the emotions that were noted after reading the digital debates, and the use of the results within the teacher training activities of the trainee teachers.

\subsection{Data Analysis}

The quantitative data were processed with both a descriptive (mode and contingency tables of absolute frequencies and relative percentages) and an inferential analysis ( $\chi^{2}$ test, Fisher's exact test, and Cramer's V). In the cases where the expected frequencies were less than 5 , the Yates correction was applied, interpreting the $p$-value of continuity correction. Likewise, qualitative-quantitative analyses (analysis of simple correspondences) were applied, with a view to describing the existence and the intensity of the relation between the categorical variables included in the instrument. The quantitative data were processed for their treatment and analysis with the SPSS v.25 statistical software package (IBM, New York, NY, USA).

Finally, for the study of the justificatory/argumentative texts of the trainee teachers, the investigation applied content analysis. These qualitative data were coded and categorized a priori. The codes were pre-defined, drawing from the review of the scientific literature [16] and the research questions. Given that the coding was aprioristic, the categories were established before the analysis and the coding was directly applied to the data. The categories were adjusted to the available information, in order to maximize their exclusivity and exhaustiveness and to reach their saturation [57].

In this analysis, two sub-phases were followed: (1) theoretical phase (pre-analytical), in which the textual units (sentences and complete textual segments) were organized and identified; (2) descriptive interpretative (analytical) phase, in which the meaning of the units were coded using the constant comparative method [58,59], and to reduce them for their classification under one of the three pre-defined independent categories (Table 2).

The analysis was completed in an iterative and recurrent manner, with the purpose of understanding the meaning of the texts written by the trainee teachers from two perspectives: (1) syntactic qualitative-quantitative perspective, through the identification of keywords and their frequency of use in the texts, which explain their manifest and/or latent emotions in relation with the above-mentioned tweets; and, (2) semantic perspective, through the categorical analysis of the narratives [60]. The methodological proposal of Santisteban [19] was used for the interpretation of the discursive arguments and their evaluation, paying special attention to the role of the emotional response and the meta-cognitive and empathic capabilities of the trainee teachers (Figure 3). 
Table 2. System of categories.

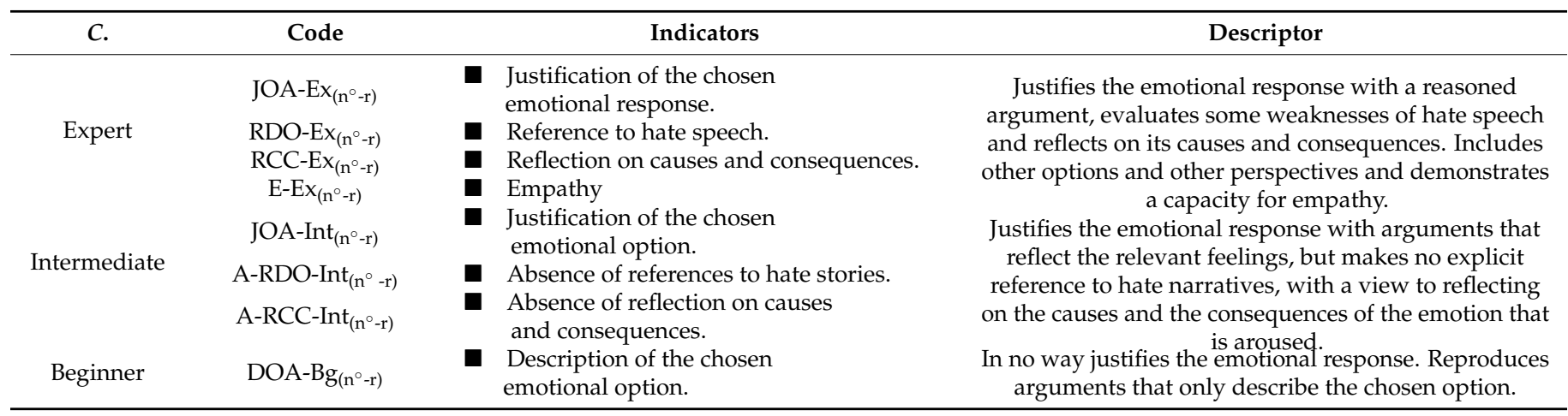

C. Category; $\mathrm{N}^{\circ}$.-r.: number of records.

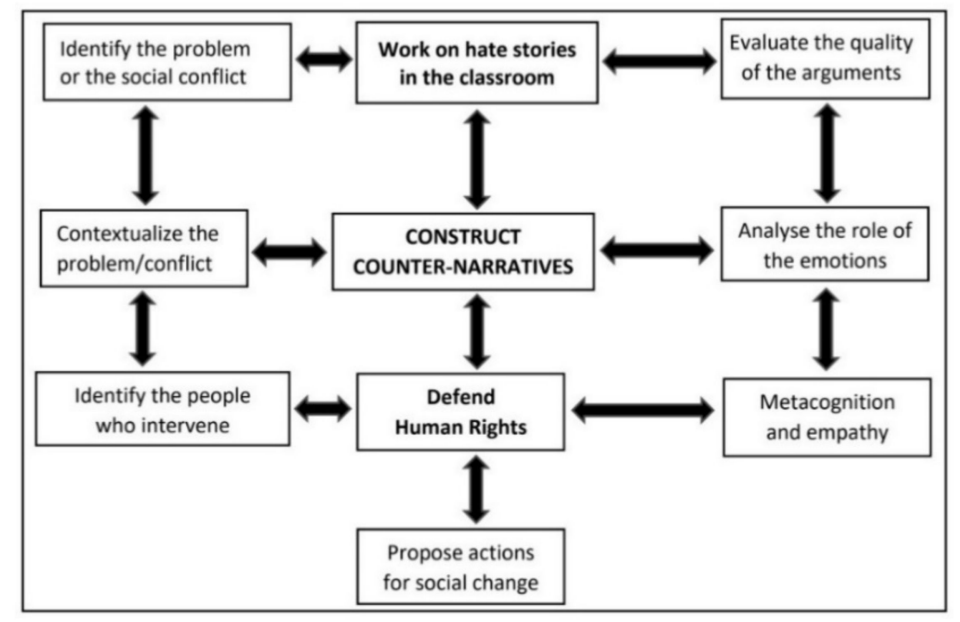

Figure 3. Construct counter-narratives to hate [19].

The content analysis complied in a satisfactory manner with the qualitative quality criteria: Confirmability (objectivity), transferability (applicability) and representativeness: the data that were collected reached their discursive saturation and their results were audited by an external researcher, which guaranteed their consistency. The content of the recording units was validated by confirming its possible assignment to a single category of analysis, the existence of a clear explanatory capacity of the categories for each of the study codes that made them up (content validity), and the degree of semantic similarity between the coding units and its categorical classification (semantic validity). Likewise, the empirical categories of the study were confirmed in accordance with the research objectives. In addition to checking the appropriateness of the proposed categorical system (validity), the consistency of the measurement procedure (reliability) was also checked. These results will be illustrated with literal fragments highlighted under each corresponding category. Credibility, dependency and trustworthiness: the consensus over the protocol and information collection procedure, and the consensus over the explanatory value of the categories and the coding are a consequence of the agreement between the members of the research team. Procedural reliability in the coding and categorisation of qualitative data was ensured by obtaining a high degree of inter-coder agreement (research team -coder 1- and external researcher -coder 2-) in relation to the criteria of stability (absence of ambiguity in the assignment of recording units to a code and category) and reproducibility (inter-researcher agreement in narrative coding) [61]. The reliability of coding and categorisation [62] was also confirmed by applying Scott's $\pi$ index $(\pi=0.82)$. Atlas.ti software was used for the segmentation of the documents into units of analysis and for their coding, categorization, and textual accountability. 


\section{Results}

\subsection{Quantitative Content Analysis}

The emotions that the trainee teachers experienced with greater frequency after reading the digital debate (activity 1 ) were anger, surprise, and happiness (Table 3 ).

Table 3. Descriptive statistics by emotional variable.

\begin{tabular}{cc}
\hline Emotion & $\boldsymbol{M}_{\boldsymbol{o}(\boldsymbol{n}=\mathbf{4 6})}$ \\
\hline Disgust/repugnance & 2 \\
Anger & 1 \\
Fear & 2 \\
Surprise & 1 \\
Happiness & 1 \\
Sadness & 2 \\
Apathy & 2 \\
\hline
\end{tabular}

$1=$ Selection of the emotional option; 2 = Absence of any selection of the emotional option.

When these frequencies were analysed by the sex of the trainee teachers, percentile differences were observed between men and women. In fact, while the vast majority of the men chose the emotion of disgust/repugnance (58.3\%), surprise $(83.3 \%)$ and happiness $(66.7 \%)$ after reading the digital debate, the women selected anger $(52.9 \%)$ and happiness $(76.5 \%)$ as their two most representative emotions (Table 4 ).

Table 4. Contingency table for the two variables: emotion and sex.

\begin{tabular}{|c|c|c|c|c|}
\hline \multicolumn{2}{|c|}{ Emotional Variable } & \multirow{2}{*}{$\frac{\text { Men }}{7}$} & \multirow{2}{*}{$\begin{array}{c}\text { Women } \\
0\end{array}$} & \multirow{2}{*}{$\frac{\text { Total }}{7}$} \\
\hline & $f_{i}$ & & & \\
\hline Disgust-repugnance & $p_{i}$ & 58.3 & 0.0 & 15.2 \\
\hline \multirow{2}{*}{ Anger } & $f_{i}$ & 6 & 18 & 24 \\
\hline & $p_{i}$ & 50.0 & 52.9 & 52.2 \\
\hline \multirow{2}{*}{ Fear } & $f_{i}$ & 2 & 8 & 10 \\
\hline & $p_{i}$ & 16.7 & 23.5 & 21.7 \\
\hline \multirow{2}{*}{ Surprise } & $f_{i}$ & 10 & 14 & 24 \\
\hline & $p_{i}$ & 83.3 & 41.2 & 52.2 \\
\hline \multirow{2}{*}{ Happiness } & $f_{i}$ & 8 & 26 & 34 \\
\hline & $p_{i}$ & 66.7 & 76.5 & 73.9 \\
\hline \multirow{2}{*}{ Sadness } & $f_{i}$ & 6 & 10 & 16 \\
\hline & $p_{i}$ & 50.0 & 29.4 & 34.8 \\
\hline \multirow{2}{*}{ Apathy } & $f_{i}$ & 4 & 0 & 4 \\
\hline & $p_{i}$ & 33.3 & 0.0 & 8.7 \\
\hline
\end{tabular}

fi: absolute frequency; pi: relative percentage.

These differences were partially confirmed through the existence of statistically significant relations between the sex of the participant and the primary emotions of disgust $/$ repugnance $\left(\chi^{2}(1, n=46)=19.09, p<0.001 ; F, p<0.001\right)$, and surprise $\left(\chi^{2}(1, n=46)=6.31\right.$, $p<0.05 ; F, p<0.05)$, two emotions linked, above all, with the men. Likewise, the existence of a significative relation was confirmed between the variable apathy and the sex of the trainee teachers $\left(\chi^{2}(1, n=46)=8.56, p=<0.01 ; F, p<0.01\right)$, an emotion that was aroused among $33.3 \%$ of the men and among $0.0 \%$ of the women. These relations registered a high intensity of association with regard to the first emotion mentioned above -disgust/repugnance(Cramer's V $=0.713, p<0.001$ ), a low intensity of association with regard to the second emotion - surprise - (Cramer's V $=0.371, p<0.05)$ and a medium-moderate intensity of association with the third emotion -apathy- (Cramer's V $=0.519, p<0.01)$. No relations of dependency were noted, in contrast, between sex and the emotional variables of anger $(p \geq 0.861)$, fear $(p \geq 0.929)$, happiness ( $p \geq 0.703)$, and sadness ( $p \geq 0.292)$ (Table 5). 
Table 5. Relation and degree of association between the emotional variables and sex.

\begin{tabular}{|c|c|c|c|c|c|c|}
\hline Emotional Variable & $x^{2}$ & $g l$ & $p$ & $p-F$ & $V$ & $p$ \\
\hline Disgust-repugnance & $19.090 * *$ & 1 & 0.000 & $0.000^{* *}$ & $0.713^{* *}$ & 0.000 \\
\hline Anger & 0.031 & 1 & 0.861 & 1 & 0.026 & 0.861 \\
\hline Fear & 0.008 & 1 & 0.929 & 1 & 0.073 & 0.620 \\
\hline Surprise & $6.317 *$ & 1 & 0.012 & 0.018 * & 0.371 * & 0.012 \\
\hline Happiness & 0.080 & 1 & 0.777 & 0.703 & 0.098 & 0.506 \\
\hline Sadness & 0.874 & 1 & 0.350 & 0.292 & 0.190 & 0.198 \\
\hline Apathy & $8.569 * *$ & 1 & 0.003 & $0.003^{* *}$ & $0.519 * *$ & 0.000 \\
\hline
\end{tabular}

${ }^{*} p<0.05 ; * * p 0.01 ; p-F$ : Fisher's exact test.

It may be concluded, in consequence, that significative relations of dependency existed between the sex of the participant and the emotions aroused by reading the digital debate on the approval of the Chilean Gender Identity Law (Research question 1). The emotional responses of disgust/repugnance, surprise, and apathy, recorded higher percentile frequencies among the men, while the emotions of anger and happiness were more frequent, although in a statistically non-significative way, among the women.

With a view to obtaining two-dimensional graphic representations of interdependency, by proximity, between the eight tweets, and the emotions they aroused (activity 2) and their textual justifications (activity 3), two analyses were performed between those two variables $\left(\chi^{2}=228.84, p<0.001\right.$, accumulated inertia $=81 \% ; \chi^{2}=879.19, p<0.001$, accumulated inertia $=58 \%)$.

As may be seen from the perceptual map (Figure 4), the emotions of surprise and happiness were associated with tweets 1, 2, 3 and 5, those of disgust/repugnance, sadness and anger with tweets 4 and 7 , fear with tweets 7 and 8 , and apathy with tweet 8 . It may therefore be affirmed that the reading of tweets 4 and 7 , especially significative for the generation of social narratives of hate, arose from the experience of negative feelings among the trainee teachers.
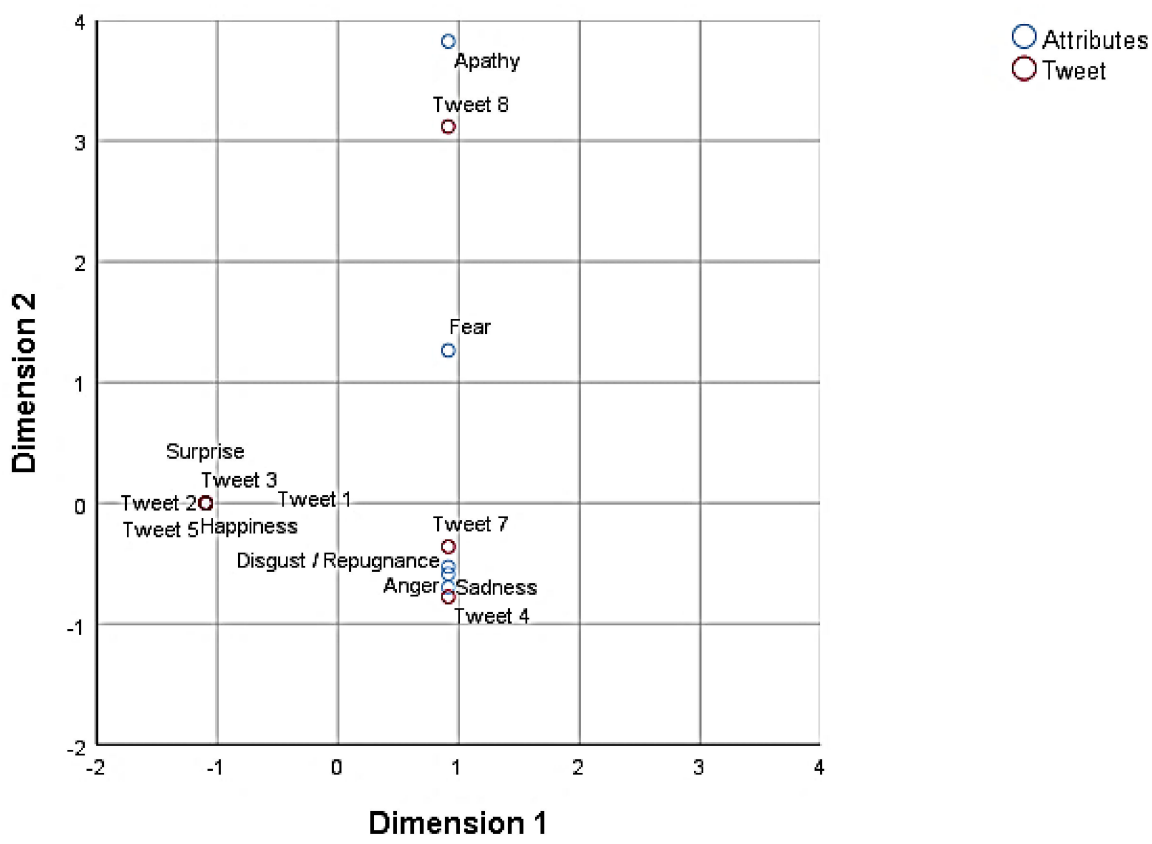

Figure 4. Positions of attributes (emotional variables) and tweets.

The absolute frequencies of the attributes associated with the eight tweets are detailed in the table of correspondences (Table 6). 
Table 6. Table of correspondences of absolute frequencies.

\begin{tabular}{|c|c|c|c|c|c|c|c|c|c|}
\hline \multirow{2}{*}{ Attributes } & \multicolumn{9}{|c|}{ Tweets } \\
\hline & Tweet 1 & Tweet 2 & Tweet 3 & Tweet 4 & Tweet 5 & Tweet 6 & Tweet 7 & Tweet 8 & Active Margin \\
\hline Disgust-repugnance & & & & 2 & & & 5 & & 7 \\
\hline Anger & & & & 4 & & & 20 & & 24 \\
\hline Fear & & & & & & & 6 & 4 & 10 \\
\hline Surprise & 6 & 7 & 4 & & & 4 & & & 21 \\
\hline Happiness & 11 & 5 & 6 & & 8 & & & & 30 \\
\hline Sadness & & & & 8 & & & 8 & & 16 \\
\hline Apathy & & & & & & & & 4 & 4 \\
\hline Active margin & 17 & 12 & 10 & 14 & 8 & 4 & 39 & 8 & 112 \\
\hline
\end{tabular}

A total of 43 key words were identified which constituted the most frequently used semantic textual units from the student narratives (activity 3). From this set, the words with a minimum recurrent frequency of five usages were analysed. Perceptual Figure 5 displays the grouping of the keywords 'freedom', 'progress', and 'equality', in relation to tweets 1, 2, 3 and 5; the association of the words 'scorn (harm)', 'misinformation', 'ignorance', and 'violence' with tweets 4 and 7; and, the absence of 'empathy' and the proximity to 'intolerance' of tweet 8 (Figure 5). These associations defined and confirmed the general relations that are established in activity 2 (Figure 4).

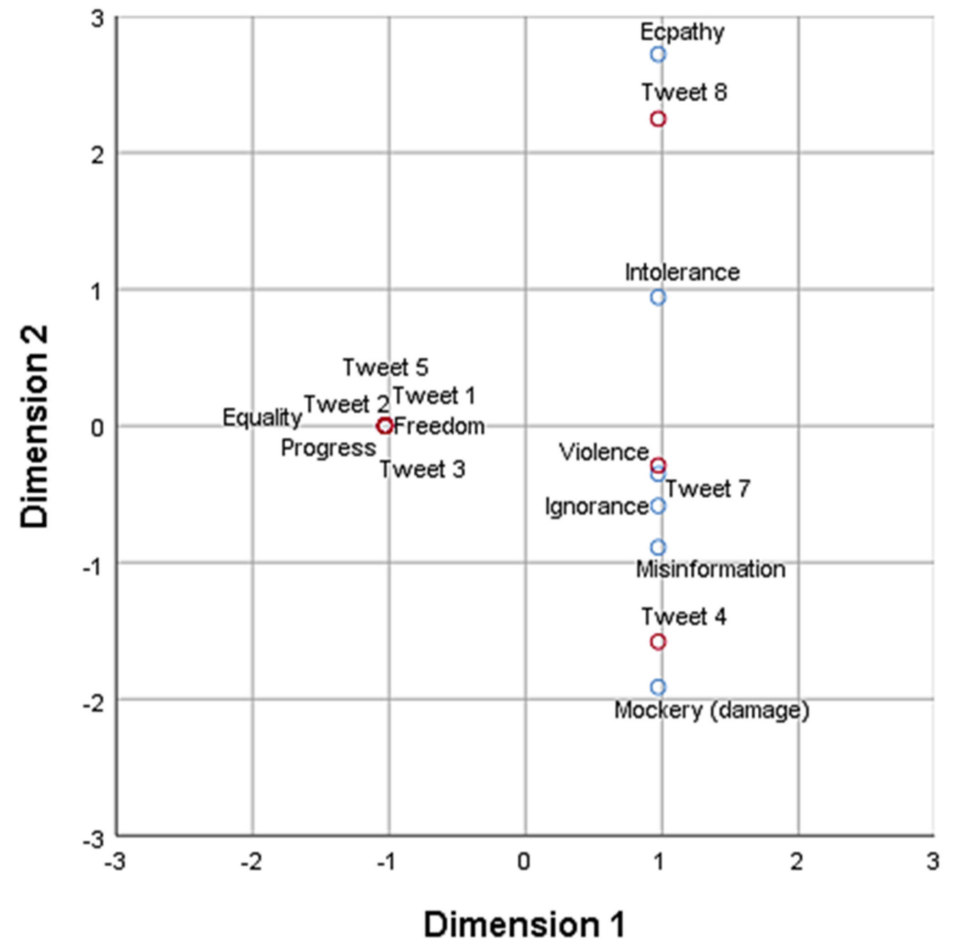

Figure 5. Positions of keywords and tweets.

The absolute frequencies of all the keywords included in the justificatory texts of the trainee teachers are detailed in the corresponding table (Table 7).

The relations represented above offer a response to the second question of the investigation, through which the existence of significative relations of interdependence may be noted between the tweets from the digital debate, the emotions that were experienced and the student narratives. In this sense, the associations of specific negative emotions (disgust/repugnance, sadness, and anger) are evident, and their justifications ('scorn (harm)', 'misinformation', 'ignorance', and 'violence') with tweets oriented toward the generation of hate stories (tweets 4 and 7). 
Table 7. Table of correspondences of absolute frequencies.

\begin{tabular}{|c|c|c|c|c|c|c|c|c|c|}
\hline \multirow{2}{*}{ Keywords } & \multicolumn{9}{|c|}{ Tweet } \\
\hline & Tweet 1 & Tweet 2 & Tweet 3 & Tweet 4 & Tweet 5 & Tweet 6 & Tweet 7 & Tweet 8 & Active Margin \\
\hline Progress & & 19 & & & & & & & 19 \\
\hline Freedom & 18 & 17 & 16 & & 16 & & & & 67 \\
\hline Intolerance & & & & & & & 22 & 16 & 38 \\
\hline Equality & 30 & & 14 & & & 17 & & & 61 \\
\hline Empathy (absence of) & & & & & & & & 17 & 17 \\
\hline Ignorance & & & & 6 & & & 34 & & 40 \\
\hline Misinformation & & & & 10 & & & 19 & & 29 \\
\hline Scorn (harm) & & & & 14 & & & & & 14 \\
\hline Violence & & & & & & & 17 & & 17 \\
\hline Active margin & 48 & 36 & 30 & 30 & 16 & 17 & 92 & 33 & 302 \\
\hline
\end{tabular}

\subsection{Qualitative Content Analysis}

The results will be presented below, beginning with the three central aprioristic categories and the most significant textual units from the 302 text excerpts.

\subsubsection{First Category: Beginner}

The narratives of the trainee teachers that describe the emotions that were selected and related with the eight tweets are contained in the first category (121 excerpts of text). These descriptions reproduce their positions toward the digital debate. However, they were not accompanied by the social, historic, or educational argumentation needed to support their attitudes.

I feel happiness because, finally, a law has been enacted that recognizes the right to equality and that rejects intolerance of gender diversities (tweets 1,3 and 6) [ ... ] [DOA-Bg $(12)]$.

It makes me feel angry, the fact that there are people, self-defined as normal, who have no empathy with those suffering from internal conflicts, because of a socially assigned gender, or that connect their intolerance toward gender diversity with an assumption that children of both sexes have an obligation to change their biological sex (tweets 7 y 8) $[\ldots]\left[\mathrm{DOA}-\mathrm{Bg}_{(15)}\right]$.

I am happy that this law of gender identity has been approved, in which everybody can feel free. I don't understand the hurtful and harmful commentaries of some people participating in the debate (tweet 4) [DOA-Bg $\left.{ }_{(22)}\right]$.

\subsubsection{Second Category: Intermediate}

The second category (173 text excerpts) includes the narratives that, although they integrate an acceptable justification for the emotional response that was selected and/or are related with the tweets, contained no explicit reference to hate, so as to reflect on its social and educational causes and consequences.

[ ... ] It makes me feel happy that part of the population welcomes this sort of progress with enthusiasm. It is clear that they recognize the right to the freedom of people that do not feel the gender [roles] that are socially recognized (tweets 1, 2 and 5) [ ... ] [JOA-Bg ${ }_{(24)}$; $\left.\mathrm{A}-\mathrm{RDO}-\mathrm{Bg}_{(24)} ; \mathrm{A}-\mathrm{RDO}-\mathrm{Bg}_{(24)}\right]$.

It disturbs me that society is so divided over a social problem that is as high-profile as this one. It also makes me indignant that people scorn it and joke about a problem that seriously affects the people that are affected and their environment (tweet 4). It is a revindication of freedom (tweet 1) and, as such, should be valued and respected [JOA-Bg $\left.(30) ; \mathrm{A}-\mathrm{RDO}-\mathrm{Bg}_{(30)} ; \mathrm{A}-\mathrm{RDO}-\mathrm{Bg}_{(30)}\right]$.

I am happy to know that there are laws that protect people that need to define their identity at a legal level. This shows that a part of the world is progressing (tweet 2). Egalitarian life is fundamental to democratic citizenship (tweet 3). Why use violence to attack a basic right? (tweet 7) [ ... ] [JOA-Bg $\left.{ }_{(3)} ; \mathrm{A}-\mathrm{RDO}-\mathrm{Bg}_{(3)} ; \mathrm{A}-\mathrm{RDO}-\mathrm{Bg}_{(3)}\right]$. 


\subsubsection{Third Category: Expert}

The third category (eight text excerpts) reunites the units of text with narratives that justify the emotional affirmations that are expressed, reflecting on the causes and the consequences of the social narratives of hate, and evidence capacity for empathy:

It is sad and it's not new. We cannot let intolerance (tweet 7) and the lack of empathy (tweet 8) continue limiting social freedom today. Consider that these people speak of ignorance and misinformation (tweets 4 and 7). That's the reason why I understand that they deny the social reality. Protection of everybody's rights from all areas of social life

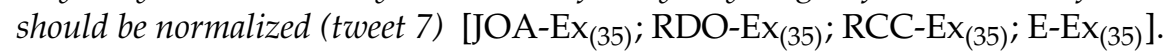

I feel surprise and, at the same time, concern for the people who, in my opinion, do not understand the relevance of the legal recognition of any right. The causes can be found, precisely, in their ignorance (tweets 4 and 7). The key is found in education [JOA-Ex $\mathrm{x}_{(41)}$;

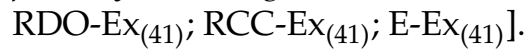

Valuing and protecting gender diversity forms part of any inclusive society, which responds to the rights of everybody. I feel fear and concern, because of the open publication of harmful comments (tweet 4) which can arise from attitudes of bullying and in violence against trans or non-binary gender [identities] (tweet 7). These sorts of attacks indicate that a lot of progress is needed. The richness of diversity must be understood through education, and being very aware of signs of intolerance (tweet 7 and tweet 8). [ . . ] Hate is not fought

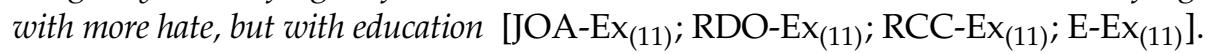

In accordance with these results, it can be confirmed that the trainee teachers tended to describe and to justify the emotions that they felt, without reaching satisfactory levels of reflection that are sufficient for the integral construction of social counter-narratives to hate (research question 3).

\section{Discussion}

The results that have been obtained have provided information on the influence of emotions and feelings that are socially constructed within the articulation of digital social narratives. Although the trainee teachers coincided in their perceptions of hate speech as obstacles to education for democratic and inclusive citizenship, their narratives neither appeared to reach satisfactory levels of reflection on the social issues that stirred their emotions, nor did they appear to situate reason alongside the value judgements expressed in the digital debate (counter-stories). Our results coincided with those of previous studies [16] uncovering the minority presence of narratives that were capable of rationalizing the incoherencies of hate stories, and providing evidence of the argumentative weaknesses of hate stories, through the emotional responses of the trainee teachers that they themselves recognized and felt. Likewise, the differences identified between the sex and the emotions of trainee teachers are found in the context of earlier works, in which the existence of emotional divergencies are confirmed, as a function of sex, in the contributions to the digital debates on Twitter [63].

Gender differences in relation to socioemotional expressions and self-regulation in educational contexts have recently been demonstrated by Veijalainen et al. [64]. Their results showed the existence of differential emotions in girls and boys in kindergarten; while girls showed emotional expressions related to calmness and peace, boys showed expressions related to surprise, anger or frustration. These differences are likewise evident in the study by Lambrecht et al. [65], whose results report differences in emotion recognition as a function of gender.

Despite the signing of the Code of Conduct on the regulation of hate speech between YouTube, Facebook, and Twitter, and the European Commission [66], we are in agreement with Lingiardi et al. [46] on the urgent need to agree on strategies and to develop preventive campaigns for the eradication of narratives against minority, ethnic, sexual, and genderspecific social groups. Likewise, we coincide with Enarsson and Lindgren [67], in that the presence of these sorts of narratives appears to expand when they form part of a 
political discussion. In fact, these open narratives operate as a social pressure valve, which contributes nothing to the treatment of and/or the solutions to constructive conflicts that seek to achieve justice and social equality [68].

In agreement with Journell et al. [69], the analyses that have been completed explain the didactic potential of social networks for the acquisition of political commitment by the university students. Likewise, we agree with Dewberry et al. [70] on the need to work with freedom of expression through democratic principles and values within the classroom. From this perspective, the results endorse the need to prepare trainee teachers for education concerning social problems, socially alive issues, and controversial topics within divided societies, considering the emotional variable as one of the most influential factors in their didactic treatment [71]. In this sense, Arneback [72] proposed the application of 'moral imagination' in education, which is to say, dwelling on the contextual elements of the social conflict, before deciding on forms of action. From this perspective, this concept has recently been applied to student teachers in order to analyze its influence on the discursive construction of their narratives on ethical dilemmas [73].

Considering emotions and feelings as categories of social analysis and working on their forms of expression constitutes one of the first procedures for education on the construction of counter-narratives to hate. This education would have to start with the identification and the contextualization of the conflict in question, and with the analysis of its origins, causes and up-dating, to continue with the critical evaluation of the emotions that intervene in the rationality of its argumentation. In second place, the acquisition and the evaluation of meta-cognitive capabilities and empathic competences by the trainee teachers would have to become an objective, whilst also considering the emotions that are aroused in them. These competences, essential to conflict resolution and in the development of critical thought, are of special importance in the treatment of social problems for the teaching of Social Sciences [74].

Education in the construction of counter-narratives to hate, as Davids [75] proposed, also implies inquiring into the limits of the forms of 'tolerable narratives' within democratic contexts and the legitimacy of the right to the expression of divergent points of view, but contrary to liberty. Hatfield et al. [76] provided one of the keys when defending the promotion of dialogical analysis to confront hate speech and to drive change within higher education.

Teaching staff have to be familiar with these narratives and work with them in the classroom, with the purpose of fighting them in dialectic readings of social reality through the construction of divergent stories (counter-narratives). Education for a democratic citizenship, the ultimate aim in the teaching of social sciences [77], contributes the methodological concepts and the resources that are needed for the deconstruction and for the disclosure of the contradictions of hate speech, and for the construction of counter-narratives based on social justice and human rights [50].

\section{Conclusions}

The relevance of proposing narratives at school that are different from those constructed by curricular materials or the mass media would start, in the first instance, from the identification and recognition of the mediating action of emotions in the construction of social narratives and, in particular, of hate speech. Only in this sense, it would be possible to oppose reason to the deconstruction of social narratives transmitted in school from the theoretical principles of education for a democratic, plural and inclusive citizenship, recognizing, consequently, the bio-cultural status of the human being [78]. In this sense, there are educational initiatives aimed at seeking curricular meeting points between the advances promoted by the Gay-Straight Alliance-Gender-Sexuality Alliance (GSA) and social studies education. Results obtained by Mayo [79] report the advantages of these intersections in promoting change in social education and in eradicating a hidden curriculum, gender differences in academic achievement [80] and "gender-blindness" [81]. 
The results obtained in the present research highlight the need to revitalize the use of critical discourses [82] on the construction of gender identities in social education. This revitalization would involve knowing how to identify the emotional mediating effects in the construction of social narratives and questioning the impact of hegemonic discourses on gender. The theoretical bases of these critical discourses would have to incorporate, at the very least, feminist practices [83], still with little relevance in Spanish curricula for the training of future social science teachers.

The systemic and structural absence of gender diversities in the social studies curriculum in Spain demands an urgent formative incorporation of the constructive mechanisms of digital discourses. Likewise, considering the differences by gender found in this study, from teacher training it is necessary to reveal the ways in which differential gender socialization occurs, in order to evaluate specific indicators on its consequences on community well-being and the creation of healthy environments [84].

\section{Limitations}

Despite the limitation of the sample size used for this study, due to the type of convenience sampling, its results can be useful for implementing teacher-training programmes on the comprehension and the interpretation of the constructive mechanisms of hate speech in the communication media and social networks, and the construction of alternative social counter-narratives in specific teacher-training contexts. The explanation for this limitation lies in the fact that the research assumes the characteristics of a case study. For this reason, a non-probabilistic convenience sampling (a type of sampling that does not seek a probabilistic representativeness) is applied.

Although the results obtained could differ if the selected participants had been active teachers, our interest was to approach the skills and competencies of trainee teachers who complete their training stage to manage their emotions in their potential participation in digital hate speech. This interest is proposed with the aim of implementing training programs aimed at using these discourses in the construction of counter-narratives from the principles of education for a democratic, plural and inclusive citizenship around gender.

Also, the emotions expressed by the trainee teachers in each of the activities proposed in the classroom constitute a large corpus of self-reported data. This circumstance could lead to biases when writing their activities and to social desirability in the argumentative orientation of their replies.

Although the social network Twitter is not the most popular social network among adolescents, we decided to analyse this digital space in view of the average age of the trainee teachers (23.3 years old), and of the consideration that all participants reported having an active account on this social network.

Author Contributions: Conceptualization, D.O.-S. and J.P.B.; Data curation, D.O.-S.; Formal analysis, D.O.-S.; Funding acquisition, D.O.-S.; Investigation, D.O.-S., J.P.B., J.I.Q., E.S.d.l.C. and R.d.l.F.-A.; Methodology, D.O.-S.; Project administration, D.O.-S., J.P.B., J.I.Q., E.S.d.l.C. and R.d.l.F.-A.; Resources, D.O.-S., J.P.B., J.I.Q., E.S.d.I.C. and R.d.I.F.-A.; Software, D.O.-S.; Supervision, D.O.-S., J.P.B., J.I.Q., E.S.d.l.C. and R.d.l.F.-A.; Validation, D.O.-S., J.P.B., J.I.Q., E.S.d.l.C. and R.d.l.F.-A.; Visualization, D.O.-S., J.P.B., J.I.Q., E.S.d.l.C. and R.d.1.F.-A.; Writing—original draft, D.O.-S. and J.P.B.; Writingreview \& editing, D.O.-S. All authors have read and agreed to the published version of the manuscript.

Funding: This research received no external funding.

Institutional Review Board Statement: The study was conducted according to the guidelines of the Declaration of Helsinki (World Medical Association Declaration), and approved by the Bioethics Commission of the University of Burgos (Spain) (IR 15/2018), thus guaranteeing the ethical-philosophical commitment and indeclinable respect for human dignity, privacy, physical and moral integrity as well as the protection of personal data in the treatment of the survey and throughout the course of the research. 
Informed Consent Statement: The informed consent of the study participants was obtained, guaranteeing the confidential treatment of the data collected. The objective and characteristics of the research were explained to them. The privacy standards were met, taking into account the code of protection of personal data (Organic Law 3/2018), of anonymity and informed consent.

Data Availability Statement: The datasets used to generate the results for this study can be obtained from the authors when deemed necessary.

Acknowledgments: This study was completed with the support of the Research Group Recognized in Didactics of History and Social Sciences (DHISO), and the Group for Educational Innovation in Didactics of Social Sciences, Languages and Literatures in Initial Teacher Training of Early Childhood Education and Primary Education (DiCSOL) of the University of Burgos. This publication is part of the R\&D Projects Teach and Learn to interpret contemporary problems and conflicts. What do the Social Sciences contribute to the formation of a critical global citizenship? (EDU2016-80145-P), financed by the Ministry of Economy and Competitiveness (Spanish Government), and Future Education and Democratic Hope. Rethinking Social Studies Education in changing times (PID2019-107383RB-I00), financed by the Ministry of Science, and Innovation Funding entity: Ministry of Economy, Industry and Competitiveness (Spanish Government). With this research: the original version of which was written with Joan Pagès Blanch during 2019 and 2020, we pay our sincerest tribute and gratitude to his teachings.

Conflicts of Interest: The authors declare no conflict of interest.

\section{References}

1. Chawinga, W. Taking social media to a university classroom: Teaching and learning using Twitter and blogs. Int. J. Educ. Technol. High. Educ. 2017, 14. [CrossRef]

2. Hitchcock, L.; Young, J. Tweet, Tweet!: Using Live Twitter Chats in Social Work Education. Soc. Work Educ. 2016, 35, 457-468. [CrossRef]

3. O'Keeffe, M. Academic Twitter and professional learning: Myths and realities. Int. J. Acad. Dev. 2018, 24, 35-46. [CrossRef]

4. Tang, Y.; Hew, K. Using Twitter for education: Beneficial or simply a waste of time? Comput. Educ. 2017, 106, 97-118. [CrossRef]

5. Akirav, O. The talk-listen-respond (TLR) model of representatives on Twitter. J. Legis. Stud. 2017, 23, 392-418. [CrossRef]

6. Bastos, M.; Mercea, D. Parametrizing Brexit: Mapping Twitter political space to parliamentary constituencies. Inf. Commun. Soc. 2018, 21, 921-939. [CrossRef]

7. Jungherr, A. Twitter use in election campaigns: A systematic literature review. J. Inf. Technol. Politics 2015, 13, 72-91. [CrossRef]

8. Rosales Sánchez, C.; Craglia, M.; Bregt, A. New data sources for social indicators: The case study of contacting politicians by Twitter. Int. J. Digit. Earth 2016, 10, 829-845. [CrossRef]

9. Tillery, A. Tweeting racial representation: How the congressional Black Caucus used Twitter in the 113th congress. Politics Groups Identities 2019, 120. [CrossRef]

10. Grace, A.; Mueller, T. Gender bias in sport media: A critical analysis of Twitter content and the National Football League's Carolina Panthers. J. Gend. Stud. 2019, 28, 363-370. [CrossRef]

11. Gurman, T.; Nichols, C.; Greenberg, E. Potential for social media to challenge gender-based violence in India: A quantitative analysis of Twitter use. Gend. Dev. 2018, 26, 325-339. [CrossRef]

12. Rogstad, I. Is Twitter just rehashing? Intermedia agenda setting between Twitter and mainstream media. J. Inf. Technol. Politics 2016, 13, 142-158. [CrossRef]

13. Evolvi, G. \#Islamexit: Inter-group antagonism on Twitter. Inf. Commun. Soc. 2017, 22, 386-401.

14. Kaufman, G.A. Odium Dicta. Libertad de Expresión y Protección de Grupos Discriminados en Internet; Consejo Nacional para Prevenir la Discriminación: Ciudad de México, Mexico, 2015.

15. Parekh, B. Hate Speech. Public Policy Res. 2006, 12, 213-223. [CrossRef]

16. Arroyo, A.; Ballbé, M.; Canals, R.; García, C.; Llusà, J.; López, M.; Oller, M.; Santisteban, A. El discurso del odio: Una investigación en la formación inicial. In Buscando Formas de Enseñar: Investigar Para Innovar en Didáctica de las Ciencias Sociales; López, E., García, C., Sánchez, M., Eds.; University of Valladolid-AUPDCS: Valladolid, Spain, 2018; pp. 423-434.

17. Spillmann, K.R.; Spillmann, K. La imagen del enemigo y la escalada de los conflictos. Rev. Int. Cienc. Soc. 1991, $127,59-77$.

18. Recomendación General $n^{\circ}$ 15, de 21 de Marzo de 2016, Sobre Lineas de Actuación en Relación con la Lucha Contra las Expresiones de Incitación al Odio; European Commission against Racism and Intolerance (ECRI): Strasbourg, France, 2016.

19. Santisteban, A. Educació política i mitjans de comunicació. Perspect. Esc. 2017, 395, 12-16.

20. Morgado, I. Emociones e Inteligencia Social: Las Claves Para Una Alianza Entre los Sentimientos y la Razón; Ariel: Barcelona, Spain, 2010.

21. Morgado, I. Emociones Corrosivas; Ariel: Barcelona, Spain, 2017.

22. Lee-Won, R.; White, T.; Song, H.; Lee, J.; Smith, M. Source magnification of cyberhate: Affective and cognitive effects of multiple-source hate messages on target group members. Media Psychol. 2019, 23, 603-624. [CrossRef]

23. Kotchemidova, C. Emotion Culture and Cognitive Constructions of Reality. Commun. Q. 2010, 58, 207-234. [CrossRef] 
24. Mondal, M.; Silva, L.; Correa, D.; Benevenuto, F. Characterizing usage of explicit hate expressions in social media. New Rev. Hypermedia Multimed. 2018, 24, 110-130. [CrossRef]

25. Council of Europe. We Can! Taking Action against Hate Speech through Counter Alternative Narratives No Hate Speech Movement; European Youth Centre: Strasbourg, France, 2017.

26. Ortega-Sánchez, D.; Pagès Blanch, J. Las representaciones sociales de los problemas contemporáneos en estudiantes de magisterio de Educación Primaria. Revista Investigación en la Escuela 2017, 1-15. [CrossRef]

27. Emcke, C. Contra el Discurso del Odio. Un Alegato en Defensa de la Pluralidad de Pensamiento, la Tolerancia y la Libertad; Taurus: Barcelona, Spain, 2017.

28. Bolaños, L.P. El estudio socio-histórico de las emociones y los sentimientos en las Ciencias Sociales del siglo XX. Rev. Estud. Soc. 2016, 178-191. [CrossRef]

29. Damasio, A. En Busca de Spinoza: Neurobiología de la Emoción y los Sentimientos; Crítica: Barcelona, Spain, 2009.

30. Escolano, A. Humanidad. Una historia de las emociones, por Stuart Walton. Hist. Mem. Educ. 2015, 2, 353. [CrossRef]

31. Errázuriz, V. Becoming "Hijas de la Lucha": Political subjectification, affective intensities, and historical narratives in a Chilean all-girls high school. Theory Res. Soc. Educ. 2021, 49, 27-53. [CrossRef]

32. Reyes-Menéndez, A.; Saura, J.; Thomas, S. Exploring key indicators of social identity in the \#MeToo era: Using discourse analysis in UGC. Int. J. Inf. Manag. 2020, 54, 102129.

33. Moscoso, J. What is the history of emotions the history of? Vinculos Hist. 2015, 4, 15-27.

34. Walton, S. Humanidad. Una Historia de las Emociones; Taurus: Mexico City, Mexico, 2005.

35. Zeeman, L.; Aranda, K.; Sherriff, N.; Cocking, C. Promoting resilience and emotional well-being of transgender young people: Research at the intersections of gender and sexuality. J. Youth Stud. 2016, 20, 382-397. [CrossRef]

36. Al-Daihani, S.; Alhaji, T. The Effect of Personal and Academic Variables on Student Adoption of Twitter as an Information Source. Int. Inf. Libr. Rev. 2017, 50, 194-201. [CrossRef]

37. Linvill, D.; Boatwright, B.; Grant, W. “Back-stage” dissent: Student Twitter use addressing instructor ideology. Commun. Educ. 2018, 67, 125-143. [CrossRef]

38. Miller, R.; Melton, J. College students and risk-taking behaviour on Twitter versus Facebook. Behav. Inf. Technol. 2015, 34, 678-684. [CrossRef]

39. Gleason, B. New literacies practices of teenageTwitterusers. Learn. Media Technol. 2015, 41, 31-54. [CrossRef]

40. Gleason, B. Thinking in hashtags: Exploring teenagers' new literacies practices on twitter. Learn. Media Technol. 2018, 43, 165-180. [CrossRef]

41. Davis, K. Teachers' perceptions of Twitter for professional development. Disabil. Rehabil. 2015, 37, 1551-1558. [CrossRef] [PubMed]

42. Visser, R.; Evering, L.; Barrett, D. \#TwitterforTeachers: The Implications of Twitter as a Self-Directed Professional Development Tool for K-12 Teachers. J. Res. Technol. Educ. 2014, 46, 396-413.

43. Watanabe, H.; Bouazizi, M.; Ohtsuki, T. Hate Speech on Twitter: A Pragmatic Approach to Collect Hateful and Offensive Expressions and Perform Hate Speech Detection. IEEE Access 2018, 6, 13825-13835. [CrossRef]

44. Zhang, Z.; Luo, L. Hate speech detection: A solved problem? The challenging case of long tail on Twitter. Semant. Web 2019, 10, 925-945. [CrossRef]

45. Waseem, Z.; Hovy, D. Hateful Symbols or Hateful People? Predictive Features for Hate Speech Detection on Twitter. In Proceedings of the NAACL Student Research Workshop, San Diego, CA, USA, 13-15 June 2016.

46. Lingiardi, V.; Carone, N.; Semeraro, G.; Musto, C.; D'Amico, M.; Brena, S. Mapping Twitter hate speech towards social and sexual minorities: A lexicon-based approach to semantic content analysis. Behav. Inf. Technol. 2019, 39, 711-721. [CrossRef]

47. Hernández, R.; Fernández, C.; Baptista, P. Metodología de la Investigación; McGraw-Hill: Ciudad de México, Mexico, 2014.

48. Schram, A. A mixed methods content analysis of the research literature in science education. Int. J. Sci. Educ. 2014, 36, 2619-2638. [CrossRef]

49. Kuckartz, U. Qualitative Text Analysis: A Guide to Methods, Practice \& Using Software; SAGE: London, UK, 2014.

50. Santisteban, A.; Díez-Bedmar, M.; Castellví, J. Critical digital literacy of future teachers in the Twitter Age. Cult. Educ. 2020, 32, 185-212. [CrossRef]

51. Castellví, J.; Díez-Bedmar, M.-C.; Santisteban, A. Pre-Service Teachers' Critical Digital Literacy Skills and Attitudes to Address Social Problems. Soc. Sci. 2020, 9, 134. [CrossRef]

52. Yin, R.K. Case Study Research: Design and Methods; SAGE: Thousand Oaks, CA, USA, 2003.

53. Creswell, J.W. Educational Research: Planning, Conducting, And Evaluating Quantitative and Qualitative Research; Pearson: Hoboken, NJ, USA, 2012.

54. Ortega-Sánchez, D. Teaching Gender in the History Classroom: An Investigation into the Initial Training of Primary Education Teachers. Educ. Sci. 2019, 9, 114. [CrossRef]

55. OECD. Panorama de la Educación. Indicadores de la OCDE 2016; Ministerio de Educación, Cultura y Deporte: Madrid, Spain, 2016.

56. Patton, M.Q. Qualitative Research and Evaluation Methods; SAGE: Thousand Oaks, CA, USA, 2002.

57. Blair, E. A reflexive exploration of two qualitative data coding techniques. J. Methods Meas. Soc. Sci. 2015, 6, 14-29. [CrossRef]

58. Bardin, L. El Análisis de Contenido; Akal: Madrid, Spain, 2002.

59. Denzin, N.K.; Lincoln, Y.S. Handbook of Qualitative Research; SAGE: Thousand Oaks, CA, USA, 1994.

60. Valles, M. Técnicas Cualitativas de Investigación Social Reflexiones Metodológicas y Práctica Profesional; Síntesis: Madrid, Spain, 2003. 
61. Krippendorff, K. Metodología del Análisis de Contenido: Teoría y Práctica; Paidós: Barcelona, Spain, 1990.

62. Muñoz Leiva, F.; Montoro Ríos, F. La medición de la fiabilidad interjuez en la codificación de preguntas abiertas: Una propuesta metodológica. In XV Spanish-Portuguese Meeting of Scientific Management; de Castro, E.D., Brândao, E., Eds.; Universidad de Sevilla: Sevilla, Spain, 2005; pp. 587-598.

63. Kerr, S.; Schmeichel, M. Teacher Twitter Chats: Gender Differences in Participants' Contributions. J. Res. Technol. Educ. 2018, 50, 241-252. [CrossRef]

64. Veijalainen, J.; Reunamo, J.; Heikkilä, M. Early gender differences in emotional expressions and self-regulation in settings of early childhood education and care. Early Child. Dev. Care 2019, 191, 173-186. [CrossRef]

65. Lambrecht, L.; Kreifelts, B.; Wildgruber, D. Gender differences in emotion recognition: Impact of sensory modality and emotional category. Cogn. Emot. 2013, 28, 452-469. [CrossRef]

66. Alkiviadou, N. Hate speech on social media networks: Towards a regulatory framework? Inf. Commun. Technol. Law 2018, 28, 19-35. [CrossRef]

67. Enarsson, T.; Lindgren, S. Free speech or hate speech? A legal analysis of the discourse about Roma on Twitter. Inf. Commun. Technol. Law 2018, 28, 1-18. [CrossRef]

68. Demaske, C. Social Justice, Recognition Theory and the First Amendment: A New Approach to Hate Speech Restriction. Commun. Law Policy 2019, 24, 347-401. [CrossRef]

69. Journell, W.; Ayers, C.; Beeson, M. Joining the Conversation: Twitter as a Tool for Student Political Engagement. Educ. Forum 2013, 77, 466-480. [CrossRef]

70. Dewberry, D.; Burnette, A.; Fox, R.; Arneson, P. Teaching free speech across the communication studies curriculum. First Amend. Stud. 2018, 52, 80-95. [CrossRef]

71. Pace, J. Contained risk-taking: Preparing preservice teachers to teach controversial issues in three countries. Theory Res. Soc. Educ. 2019, 47, 228-260. [CrossRef]

72. Arneback, E. Moral imagination in education: A Deweyan proposal for teachers responding to hate speech. J. Moral Educ. 2014, 43, 269-281. [CrossRef]

73. Hyry-Beihammer, E.; Lassila, E.; Estola, E.; Uitto, M. Moral imagination in student teachers' written stories on an ethical dilemma. Eur. J. Teach. Educ. 2020, 1-15. [CrossRef]

74. Yuste, M. L'Empatia i L'Ensenyament-Aprenentatge de les Ciències Socials a L'Educació Primària a Catalunya. Un Estudi de Cas. Ph.D. Thesis, Autonomous University of Barcelona, Catalonia, Spain, 2016.

75. Davids, N. On the (in)tolerance of hate speech: Does it have legitimacy in a democracy? Ethics Educ. 2018, 13, 296-308. [CrossRef]

76. Hatfield, K.; Schafer, K.; Stroup, K. A Dialogic Approach to Combating Hate Speech on College Campuses. Atl. J. Commun. 2005, 13, 41-55. [CrossRef]

77. Ortega-Sánchez, D.; Pagès Blanch, J. The End-Purpose of Teaching History and the Curricular Inclusion of Social Problems from the Perspective of Primary Education Trainee Teachers. Soc. Sci. 2020, 9, 9. [CrossRef]

78. Boddice, R. The History of Emotions: Past, Present, Future. Rev. Estud. Soc. 2017, 10-15. [CrossRef]

79. Mayo, J. Expanding the Meaning of Social Education: What the Social Studies Can Learn from Gay Straight Alliances. Theory Res. Soc. Educ. 2013, 41, 352-381. [CrossRef]

80. Richardson, J.; Mittelmeier, J.; Rienties, B. The role of gender, social class and ethnicity in participation and academic attainment in UK higher education: An update. Oxf. Rev. Educ. 2020, 46, 346-362. [CrossRef]

81. Ullah, H.; Skelton, C. Gender representation in the public sector schools textbooks of Pakistan. Educ. Stud. 2013, 39, 183-194. [CrossRef]

82. Segall, A. Revitalizing Critical Discourses in Social Education: Opportunities for a More Complexified (Un)Knowing. Theory Res. Soc. Educ. 2013, 41, 476-493. [CrossRef]

83. Schmeichel, M. Skirting Around Critical Feminist Rationales for Teaching Women in Social Studies. Theory Res. Soc. Educ. 2015, 43, 1-27. [CrossRef]

84. Migliorini, L.; De Piccoli, N. Challenging gender perspective in the community to promote well-being and health. J. Prev. Interv. Community 2020, 48, 121-131. [CrossRef] [PubMed] 